Article

\title{
The European Green Deal: What Prospects for Governing Climate Change With Policy Monitoring?
}

\author{
Jonas J. Schoenefeld ${ }^{1,2}$ \\ ${ }^{1}$ Institute for Housing and Environment (IWU), Germany; E-Mail: j.schoenefeld@iwu.de \\ ${ }^{2}$ Tyndall Centre for Climate Change Research, School of Environmental Sciences, University of East Anglia, UK
}

Submitted: 29 March 2021 | Accepted: 13 July 2021 | Published: 30 September 2021

\begin{abstract}
The European Green Deal (EGD) puts forward and engages with review mechanisms, such as the European Semester and policy monitoring, to ensure progress towards the long-term climate targets in a turbulent policy environment. Soft-governance mechanisms through policy monitoring have been long in the making, but their design, effects, and politics remain surprisingly under-researched. While some scholars have stressed their importance to climate governance, others have highlighted the difficulties in implementing robust policy monitoring systems, suggesting that they are neither self-implementing nor apolitical. This article advances knowledge on climate policy monitoring in the EU by proposing a new analytical framework to better understand past, present, and potential future policy monitoring efforts, especially in the context of the EGD. Drawing on Lasswell (1965), it unpacks the politics of policy monitoring by analysing who monitors, what, why, when, and with what effect(s). The article discusses each element of the framework with a view to three key climate policy monitoring efforts in the EU which are particularly relevant for the EGD, namely those emerging from the Energy Efficiency Directive, the Renewable Energy Directive, and the Monitoring Mechanism Regulation (now included in the Energy Union Governance Regulation), as well as related processes for illustration. Doing so reveals that the policy monitoring regimes were set up differently in each case, that definitions of the subject of monitoring (i.e., public policies) either differ or remain elusive, and that the corresponding political and policy impact of monitoring varies. The article concludes by reflecting on the implications of the findings for governing climate change by means of monitoring through the emerging EGD.
\end{abstract}

\section{Keywords}

climate policy; energy efficiency; energy policy; Energy Union; European Green Deal; Monitoring Mechanism; Paris Agreement; policy monitoring; renewable energy; soft governance

Issue

This article is part of the issue "Climate Governance and the European Green Deal in Turbulent Times" edited by Claire Dupont (Ghent University, Belgium) and Diarmuid Torney (Dublin City University, Ireland).

(C) 2021 by the author; licensee Cogitatio (Lisbon, Portugal). This article is licensed under a Creative Commons Attribution 4.0 International License (CC BY).

\section{Introduction}

Policy monitoring (hereafter "monitoring") may be understood as "a continuous process of collecting and analysing data to compare how well a project, program, or policy is being implemented against expected results" (OECD-DAC, 2002, p. 30). Monitoring has long been considered a suitable governance tool to enable progress in turbulent times; that is, in "situations where events and demands interact in a highly variable, inconsistent, unexpected, and/or unpredictable manner" (Ansell et al.,
2017, p. 7; Dobbs et al., 2021). In these volatile policy environments, monitoring has often been assumed to generate a steady stream of insights about the direction of travel and be a basis for policy adjustment (see Rist $\&$ Stame, 2011). Continuous feedback, so the thinking goes, may enable a more flexible and dynamic form of governance commensurate with the demands of turbulence and its difficult politics. Implicitly, policy monitoring has thus been viewed as an important ingredient in governing "with turbulence" (Dobbs et al., 2021). Existing evidence suggests that doing so is a long-standing strategy: 
Nearly 30 years ago, the EU pursued monitoring at the creation of the United Nations Framework Convention on Climate Change (UNFCCC) in 1992, because agreeing on substantial climate policy (such as a carbon tax) proved impossible (Haigh, 1996). Yamin and Depledge have consequently identified monitoring and review as "the backbone of the climate regime" (2004, p. 327).

More than two decades later, the EU found that negotiating binding emissions targets or even concrete policies still proved too contentious for agreement at the international level, so it once again focused on monitoring and review processes in the negotiation of the 2015 Paris Agreement (Held \& Roger, 2018). Article 13 of the Paris Agreement prescribes that all parties to the agreement must monitor and report on their greenhouse gas emissions and their corresponding climate policy efforts to curb emissions. Summing up the key features of the current, Paris-based governance approach, Held and Roger argue that "the review process... must provide accurate information about what states are and are not doing" (2018, p. 535).

Responding to these international developments, the EU's new strategy for governing climate change and the environment, the European Green Deal (EGD) communication (European Commission, 2019), also relies significantly on policy review and monitoring provisions. For example, on page 3 , the document reads that "the Commission will refocus the European Semester process of macroeconomic coordination (a monitoring and review system, see Bocquillon et al., 2020) to integrate the United Nations' sustainable development goals" (European Commission, 2019, p. 3). Re-thinking the European Semester and particularly its indicators has been highlighted as one of the key issues in implementing the EGD, especially with a view to the UN Sustainable Development Goals, but also the EU's Stability and Growth Pact (Laurent, 2020). Furthermore, the EGD highlights the member state National Energy and Climate Plans on page 6 , which also contain monitoring provisions (Knodt et al., 2020). Furthermore, the Green Deal communication emphasises the need for non-financial company reporting (European Commission, 2019, p. 17) and refers to the better regulation initiative by the Commission (European Commission, 2019, p. 19), which stresses the crucial role of policy monitoring and evaluation (Radaelli, 2018). In the context of a new Environmental Action Programme, there will be "a new monitoring mechanism to ensure that Europe remains on track to meet its environmental objectives. The Commission will also launch a dashboard to monitor progress against all of the European Green Deal objectives" (European Commission, 2019 , p. 23). As there is a headline target of reaching carbon neutrality by mid-century (if not before) and an evident prominence of monitoring in the EGD provisions, what are their prospects for contributing to successful environment and climate governance?

Given the decades-long history of monitoring and its prominence in the EGD, it is striking how little attention has been paid to it. Scholars have at best scratched the surface while exploring the characteristics of monitoring schemes and factors that may foster or hinder successful monitoring. Some have highlighted the political nature of related policy evaluation (e.g., Bovens et al., 2006), but more systematic approaches to investigate monitoring schemes and the data they produce have only been undertaken more recently (Bürgin, 2021; De Francesco et al., 2020; Schoenefeld et al., 2021; Tosun, 2012). While some publications have centred on the plausibility and quality of climate monitoring data (Hildén et al., 2014; Schoenefeld et al., 2018) or aspects of implementing policy monitoring (Jones, 2010; Schoenefeld et al., 2019), a more general framework for analysing the politics of policy monitoring is currently missing (see also Schoenefeld \& Rayner, 2019)-even though the theoretical and practical importance of monitoring has repeatedly been highlighted (Aldy, 2014, 2018; Cumming \& Forbes, 2012; Peeters \& Athanasiadou, 2020).

This article seeks to fill this gap by offering a novel framework to analyse and understand the politics of policy monitoring in Section 2. Doing so responds to a long-standing misconceptualisation of policy monitoring as an apolitical means of governing, which has been admonished time and again but remains a strangely persistent assumption among many academics and practitioners (for a discussion of this phenomenon, see Hildén et al., 2014). Such a limited understanding severely hampers the conceptualisation and comprehension of the potential of policy monitoring to governing (with) turbulence. To propose a better framework for analysing and understanding monitoring, this article draws on Lasswell's (1965) famous definition to unpack the politics of policy monitoring by analysing who monitors, what, why, when, and with what effect(s). In introducing the framework, this article relates each constituting element to extant monitoring schemes, focusing on energy efficiency and renewable energy policies, the broader Monitoring Mechanism in the EU, and other processes. The Energy Efficiency Directive and the Renewable Energy Directive are of high relevance to curbing greenhouse gas emissions in the $\mathrm{EU}$, while the Monitoring Mechanism Regulation aims to generate an overview across climate policies in the EU member states (the Monitoring Mechanism Regulation has now been incorporated in the Energy Union Governance Regulation [2018/1999], but the underlying monitoring regime remains intact). Section 3 brings together the emerging insights and discusses them in the context of the EGD, which relies in part on monitoring. Doing so opens numerous avenues for future research and offers monitoring design choices to practitioners.

\section{Analysing Policy Monitoring: Towards a New Framework}

Back in 1965, Lasswell famously wrote that "politics is the study of who gets what, when and how" (1965, p. 
3). This article draws on Lasswell's early thinking to propose a new framework for analysing the politics of policy monitoring schemes. It centres on who monitors, what, why, when, and with what effect(s). Existing literature (e.g., Aldy, 2014; Tosun, 2012) has already begun to analyse policy monitoring actors and their relationships (who), monitoring content (what), rationales for policy monitoring (why), the timing of policy monitoring (when), and the policy outputs and outcomes of monitoring schemes (effects). However, these elements have typically been discussed in isolation, generating fragmentation and a paucity of cumulative insight. The remainder of this section unpacks the proposed framework and relates each element to existing literature and the EGD to illustrate their plausibility. Table 1 summarises the main points of the framework in the context of past experiences with monitoring energy efficiency and renewable energy policy in the EU, as well as the Monitoring Mechanism/Energy Union Governance Regulation.

\subsection{Who Monitors?}

The who question addresses the actors and institutions that partake in monitoring schemes (Waterman \& Wood, 1993). To better understand monitoring actors, the distinction between the role of public (i.e., governmentdriven) and private (i.e., society-driven) policy monitoring actors has proven useful (Gupta \& Mason, 2016). Many of the advantages and disadvantages of private and public actors that have been identified in the context of policy evaluation (see Schoenefeld \& Jordan, 2017; Weiss, 1993) also apply to monitoring. For example, public actors may have more resources to finance monitoring processes (see Mayne \& Zapico-Goñi, 1997). Public actors may furthermore have better access to relevant data in monitoring efforts or may be able to steer governments towards generating such data. By contrast, non-governmental actors may also command considerable resources and may be more independent than governmental actors, but they may also potentially be interest driven.

The relationship between those who monitor and those subjected to monitoring has consequences: If actors come to understand monitoring processes as learning opportunities (see Sabel, 1993), they may happily provide the relevant data and derive lessons from them to improve their own policy-making endeavours. If policy monitoring becomes a control mechanism to check compliance against targets or potentially decide on the (dis)continuation of certain policies, then the motivation to provide data may be much lower. Tensions between actors may also emerge because policy monitoring is not free-on the contrary, it requires monetary and personnel resources (Leeuw, 2010; Mayne \& Zapico-Goñi, 1997). Conflicts may thus emerge over monitoring and reporting's cost and administrative burden, as well as the perceived usefulness of the outputs a policy monitoring mechanism generates. While monitoring refers to the processes of regular data collection and collation, reporting refers to the transfer of data from one actor to another, often across governance levels. Data availability also has the potential to shift the power relations among different agents in governance systems, potentially impinging on interests (Hughes et al., 2019).

In the cases of energy efficiency and renewable energy, the EU directives prescribe that the member states report on their policies to the European Commission. The relationship is hierarchical, with nonimplementation of monitoring potentially leading to infringement procedures before the Court of Justice of the European Union (CJEU). The Monitoring Mechanism also includes the European Environment Agency as an implementing actor between the member states and the Commission. The EEA quality checks the monitoring data, publicises, and forwards them to the European Commission, which in turn uses them in its own reporting to the UNFCCC (Schoenefeld et al., 2019). The relationship between the actors is similar to the previous two directives; Luxembourg has already faced the CJEU twice for untimely reporting (Schoenefeld et al., 2018). The inclusion of these monitoring streams in the National Energy and Climate Plans in the Energy Union has shifted the relationship between the Commission and the member states. In cases of ambition or delivery gaps, the Commission can act and has therefore strengthened its hand through monitoring (Knodt \& Ringel, 2018).

Non-state actors also engage in policy monitoring. A notable example is the Climate Action Tracker (https://climateactiontracker.org/about), a consortium that provides a range of data on renewable energy deployment, efficiency in the building sector and, above all, greenhouse gas emissions. Doing so yields country reports and worldwide assessment of climate action progress. The Climate Action Tracker prides itself in being independent of governments, whose activities it monitors, especially with a view to the pledges that countries submitted under the Paris Agreement. However, it should also be noted that the Climate Action Tracker has received support grants from the German Federal Government. Taken together, both governments and private initiatives regularly monitor climate policies. This framework suggests that there is value in exploring monitoring actors as well as how their interests may shape the monitoring. This is especially true for the emerging design of the EGD, which appears to mainly rely on government-driven monitoring, potentially neglecting the growing ability and role of non-state actors in policy monitoring. However, the EGD monitoring does aim to link with international efforts through the UN SDGs.

\subsection{What Do They Monitor?}

The second element of the framework concerns what is being monitored, typically expressed through the data that monitoring processes generate. From a conceptual perspective, Dunn (2018) distinguishes between 
monitoring policy inputs (e.g., resources invested), policy outputs (e.g., laws on the statute books), and policy outcomes/impacts (i.e., what is actually being achieved). There are numerous ways in which monitoring may be conducted, ranging from "social systems accounting" (i.e., broad, headline indicators such as the unemployment rate), "policy experimentation" (i.e., the more or less controlled application of policy approaches to a sub-section of the population), "social auditing" (i.e., capturing the connection between inputs, outputs and outcomes of policies), "research and practice synthesis" (e.g., compiling knowledge from case studies and research reports), as well as "systematic reviews and meta-analyses" (i.e., more systematised analysis of a particular research question based on existing studies) that could all be a basis for monitoring (Dunn, 2018). In other words, the what question also incorporates important methodological questions and choices.
Each broad area translates into a plethora of potential individual indicators (Kenney \& Gerst, 2021; Lehtonen, 2015) that may be used, such as dollars/euros invested, the numbers of laws on the statute books, or the level of pollutants in the air. However, not every monitoring approach is equal; it often tends to be easier to monitor policy outputs than outcomes. For example, while taxation, installation, and electricity production data generally allow for good estimates of the amounts of solar panels installed in a country, estimating policy impact on greenhouse gas emissions is more challenging, given that doing so involves life cycle analysis of solar panels, energy substitution behaviour, and so on. In the area of energy policy, there have, for example, been endeavours to track the amount of money being invested in subsidies for nuclear or renewable energy over time (Küchler \& Meyer, 2012). Scholars have furthermore counted the climate laws that countries have put

Table 1. Analysing policy monitoring in energy efficiency, renewables, and general monitoring of climate policies.

\begin{tabular}{llll}
\hline Case & Energy Efficiency & Renewable Energy & $\begin{array}{l}\text { Monitoring Mechanism (now } \\
\text { incorporated in the Energy Union } \\
\text { Governance Regulation) }\end{array}$ \\
\hline Who & $\begin{array}{l}\text { Member states collect data and } \\
\text { report them to Commission; }\end{array}$ & $\begin{array}{l}\text { Member states collect data and } \\
\text { Commission conducts analyses. }\end{array}$ & $\begin{array}{l}\text { Member states collect data and } \\
\text { report them to the European }\end{array}$ \\
& $\begin{array}{l}\text { Article } 7 \text { of the directive requires } \\
\text { that independent authorities }\end{array}$ & Commission. The European \\
& & Environment Agency assists in \\
\end{tabular}

conduct the monitoring (varies by member state).

What Energy savings.

Mainly projected and/or achieved (soft language in the directive).

Why

To track policy developments in the member states and improve them.

When Report every year on the achievement of the targets (from 2013).

National Energy Efficiency Action Plans every 3 years (from 2014).

Effects No assessments available.

Sources latridis et al. $(2015,2016)$; Kanellakis et al. (2013); Pereira and da Silva (2017); Ringel (2017); Rosenow et al. (2015).
Commission must monitor origins of biofuels, as well as their greenhouse gas savings, based on reports from the member states.

Article 24: Transparency platform that publishes national plans, statistical transfers, and projections.

Unclear.

Every other year (starting in 2011).

No assessments available.

Howes (2010); Kanellakis et al. (2013).
Greenhouse gas reduction per policy.

Cost per policy.

Ex-ante data mandatory; ex-post data voluntary.

To track policy development and fulfil reporting duties to the UNFCCC.

Every other year (first data available from 2009).

Greenhouse gases every year.

No assessments available.

Hildén et al. (2014); Schoenefeld and Jordan (2020); Schoenefeld et al. (2018); Schoenefeld et al. (2019); Schoenefeld et al. (2021). 
into place worldwide (Averchenkova et al., 2017), while others have tracked private initiatives that address climate change (Hsu et al., 2019). Then there have equally been the considerable efforts under the UNFCCC and the Intergovernmental Panel on Climate Change (IPCC) to account for the release of greenhouse gases into the atmosphere (Calvo Buendia et al., 2019; Eggleston et al., 2006), as well as other efforts to track energy flows, such as coal, oil, or gas (Eurostat, 2016). Conceptually, Mayne and Zapico-Goñi (1997) explain that performance measures should be purpose- (rather than data- or practicality-) driven.

In the area of energy efficiency policy, the EU's focus is on energy savings-i.e., policy outcomes. Indicators here include the cumulative reduction in annual energy sales in absolute numbers and percentage reductions as well as, for example, renovation rates for public and private buildings (expressed in \%). Article 24 of the Energy Efficiency Directive allocates progress monitoring tasks to the Commission, and details that it must report to the European Parliament and the Council, and include the findings in other reporting exercises, such as the Energy Union reports (Schoenefeld \& Knodt, 2021). The reporting requirements include both retrospective and prospective elements. Earlier papers have, however, admonished that "[a]t present, Member States are free to decide themselves on the appropriate measuring and have no obligation to use any harmonised M\&V scheme" (Ringel, 2017, p. 761). For example, in Germany, the National Statistical Office plays an important role in collating energy efficiency data, which is mainly generated by a public-private partnership that in turn uses data from the regional and local administrations (Ringel, 2017). At the European level, this mode of policy monitoring has led to varying levels of data quality, a lack of transparency of energy-saving calculation methods, and incomplete reporting (Rosenow et al., 2015).

The Renewable Energy Directive is equally detailed in its legal provisions, where for example, Article 7 includes clear prescriptions on how to calculate the national renewable energy share (a form of standardisation). However, the reporting requirements are more general and mainly focus on the share of renewables in the member states and lists existing and planned policies and measures to achieve this. Finally, the Monitoring Mechanism contains per-policy quantification of projected greenhouse gas reductions but minimal ex-post data. Over time, the number of indicators has also been expanded to include information on the costs of policies. However, much of the additional monitoring remains voluntary, drawing limited member state interest. The monitoring of state progress through the nationally determined contributions (Paris Agreement), as well as monitoring the steps towards achieving carbon neutrality by 2050, which has recently been enshrined in the EU's new climate law, has also further increased the relevance of monitoring. In the EGD, especially the focus on a "just transition" will be a key question for monitoring (and also evaluation). In its current form, the EGD mainly relies on the European Semester to assess national policymaking. But monitoring a just transition may require a broader range of evidence, including potentially qualitative aspects, which reach beyond the limited frameworks that have, for example, featured in EU cohesion policy (Batterbury, 2006). Whether the dashboard as part of the new environmental action programme will contain such considerations remains to be seen.

\subsection{Why Do They Monitor?}

Both practitioners and academics usually understand policy monitoring as a means to an end. But to what end(s)? One reason is to make public policy efforts more transparent. The Oxford English Dictionary defines the adjective "transparent" as "easily seen through, recognised, understood, or detected; manifest, evident, obvious, clear" and transparency in turn as "the quality or condition of being transparent." The core idea behind the concept of transparency is that knowledge about the behaviour of others, in turn, changes behaviour (or policies) or reinforces desirable actions (but there are also cautionary voices, see Hillebrandt, 2020; Weikmans et al., 2020). Relatedly, Elinor Ostrom (1990, p. 45) stresses that " $[\mathrm{w}]$ ithout monitoring, there can be no credible commitment; without credible commitment, there is no reason to propose new rules." In the context of the EU Energy Union and the Monitoring Mechanism, efforts to increase the public availability and visibility of the monitoring data have become apparent: Whereas the Energy Union reports have become a prominent platform to showcase energy efficiency and renewable energy data (Schoenefeld \& Knodt, 2021), the European Environment Agency has made concerted efforts to generate online platforms and a data viewer to increase the visibility of the data (Schoenefeld \& Jordan, 2020).

Actors may also engage in policy monitoring because they face international pressure, or are actively being monitored by international institutions, such as the European Commission or the OECD. For example, in the case of the EU member states, pressure comes from the Paris Agreement, the Governance Regulation, and of course the EGD, which demand regular monitoring. Those who monitor may be interested in actively steering or coordinating policy action at lower governance levels through policy monitoring (Schoenefeld \& Rayner, 2019). This ultimately signifies some level of control being exerted by those who monitor public policies. However, actors may also monitor because they wish to learn, perhaps even peer-to-peer (see Aldy, 2018; Sabel, 1993). Acquiring new information about one's own activities and those of others can be a source of learning (see Gerlak et al., 2017).

Just as scholars have stressed regarding policy evaluation (e.g., Bovens et al., 2006), policy monitoring may also be conducted for political or tactical reasons that have less to do with the learning and steering functions 
detailed above. Policy monitoring may be used as a signalling tool to set the agenda or hide insufficient policy action (Schoenefeld \& Jordan, 2019). In its first attempt to make a mark on international climate politics, the EU arguably chose this route and pursued monitoring, given its own inability to agree on a domestic carbon tax (Haigh, 1996; Yamin \& Depledge, 2004). As Gupta and Mason (2016, p. 88) therefore highlight, "disclosure is itself a site of contestation, rather than a (neutral) means to help transcend political conflicts." These political aspects of monitoring demand attention. So far, the EU has often sought to depoliticise monitoring and avoid, for example, ranking countries to enable naming and shaming, a general approach that the EGD has picked up once again.

\subsection{When Do They Monitor?}

Mayne and Zapico-Goñi (1997, p. 18) highlight that useful performance measures have to be timely. For example, are there dedicated reporting cycles? How often does policy monitoring happen? And what role does policy monitoring play in "closing the policy cycle" (see Mastenbroek et al., 2016)? The timing of policy monitoring is thus another key factor, especially in relation to other policy developments. As Puaschunder (2021) highlights with a view to the EGD, policy outcomes will need to be observed over extended periods to capture their full effects. Then there is the temporal orientation of policy monitoring itself: Monitoring data may be either forward-looking or prospective (ex-ante), that is, assessing future policy impacts, or they may be retrospective (ex-post), that is, monitoring past policy impacts. These distinctions are by no means purely technical. Politically, ex-ante predictions may be less "threatening" to certain actors than ex-post assessments of what they have actually (not) achieved (Schoenefeld \& Jordan, 2019).

In the cases reviewed in this article, there are recurrent monitoring cycles, creating predictable monitoring outputs. An innovation in the Energy Union governance is that there are concrete prescriptions on Commission assessments with a view to revising targets and instruments. Furthermore, the Monitoring Mechanism has been closely aligned with effort sharing processes at the EU level, another attempt to increase the consequentiality of monitoring (Schoenefeld \& Jordan, 2020). This has been done, in turn, as the EU has adjusted its own policy cycles to the rhythm of the Paris Agreement. Putting monitoring in sync with policymaking may increase the effectiveness of the former. Taken together, there is a clear trend towards better alignment of monitoring processes with policymaking in various substantial policy areas.

One challenge of the EGD and the associated legislation is that they contain long-term targets (e.g., carbon neutrality) and concepts (such as justice and fairness), which require profound change, including far-reaching social change. Aspects such as social justice or resilience are difficult to capture with single indicators to assess progress against targets. A broad range of indicators, combined with qualitative evidence, will likely be necessary for a more comprehensive and continuous assessment over time. The link with the SDGs and their indicators in the EGD is one promising aspect in terms of monitoring progress (see Schoenefeld et al., in press).

\subsection{To What Effect Do People Monitor?}

While previous research has typically viewed monitoring as a tool to assess the effects of policies, emerging work suggests that the existence and operation of monitoring systems may have a range of potential political and substantial effects. For example, if monitoring helps strengthen policy implementation or provides a basis for revising governance targets, then substantial effects may flow from it. Given that there are multiple reasons why actors engage in policy monitoring, there is no straightforward answer to what the potential political and/or substantial effects may be, creating an important need to investigate real-world instances of policy monitoring empirically. Relevant questions include: Does policymaking become more transparent, do steering effects emerge, and can we observe the more political elements of policy monitoring? Importantly (and challengingly), can we trace the (often implicitly assumed) causal mechanisms running from the existence of monitoring to observed impacts? There are in principle multiple ways in which policy monitoring may be conceptualised in empirical investigations: as an independent variable in order to explain certain outcomes (essentially the rationale above); as an explanatory tool in order to assess the existence of other causal mechanisms running from policy inputs to impacts (see Dunn, 2018, p. 255); as an intervening variable as part of another policy input-impact mechanism; or finally as a dependent variable that can be explained with other, independent variables.

Considering the growing emphasis on monitoring and review in the context of the EGD, Paris Agreement, the EU Energy Union, and specific pieces of legislation on energy efficiency, renewable energy, and the Monitoring Mechanism (now incorporated in the Energy Union Governance Regulation), there is certainly an underlying assumption that these processes are or will become important elements of effective climate governance in turbulent environments. However, the extent to which this assumption is true is an open empirical question ripe for detailed exploration; some scholars, such as Puaschunder (2021), have raised doubts about whether the existing monitoring regimes are sufficient for the EGD's bold aims because they, for example, omit consumption-based emissions. Laurent (2020) has pointed to the limitations of the existing indicators contained in the EGD and the need to thoroughly re-think the European Semester and key indicators contained therein.

So far, there are no structured empirical investigations that assess the effects of monitoring systems. Some authors have warned that "[g]ood performance 
information on its own is not going to reform the public sector" (Mayne \& Zapico-Goñi, 1997, p. 12). One could, by extension, argue that good policy monitoring alone is unlikely to put the world or the EU on track to achieve its aims under the Paris Agreement. Waterman and Wood (1993) have likewise cautioned that policy monitoring should not be viewed as a panacea. Putting monitoring in place could also generate desired or undesired side effects, such as the empowerment of executive agencies involved with monitoring activities in the EU (Jevnaker \& Saerbeck, 2019; Trondal, 2016). There is, in sum, no reason to assume that policy monitoring will necessarily produce the desired effects, and thus a need for careful empirical analysis to trace the factors that may drive impactful monitoring and what impacts it generates.

\section{Conclusions and Future Directions}

Practices of policy monitoring-which include policy monitoring, reporting, and data evaluation-have become ever more central in EU policy-making, including in the EGD. They have been presented as suitable tools to address turbulent policymaking around and within EU institutions, especially in the conflict-prone area of climate change and energy policy. Despite the growing prominence of monitoring, so far scholars have by and large neglected it-a gap that this article addressed by proposing a new analysis framework (based on Lasswell's early insights on politics) and by conducting a first plausibility probe. The novel framework is chiefly a tool for analysing existing monitoring schemes, but it may equally serve as a resource for practitioners seeking to set up monitoring schemes as it makes monitoring design choices explicit (see also Schoenefeld \& Jordan, 2017). The framework demonstrates that there are many different potential variations of policy monitoring, which emerge as unique combinations of design characteristics that include who monitors, what they monitor, why they monitor, when they monitor, and with what effects. The plausibility probe has demonstrated that the framework's elements can be identified in the context of climate policy in the EU and the emerging EGD.

The biggest unexplored issue relates to the effectiveness of monitoring. As a key element of the framework, the effects of policy monitoring in terms of enabling steering, learning, and ultimately advancing climate action under conditions of turbulence are a key area for future research. Turbulence in EU climate and energy governance has emerged as one of the drivers of monitoring schemes, as other policy options have often remained beyond reach. The extent to which monitoring is, in turn, a suitable tool to govern turbulence remains a key future research priority. Given the multiple design options for monitoring schemes, particularly the connection between different monitoring design options and effective governance requires attention.

What implications emerge from these findings for the EGD? The EGD builds on several existing monitor- ing provisions, thus representing a key empirical example where monitoring is being used to govern in turbulent times. It relies on the EU's monitoring within existing frameworks that have long been in existence, but which have been enhanced in various ways, for example, in the context of the Energy Union. Whether doing so is sufficient remains an open question-with a view to monitoring the EGD, Puaschunder (2021, p. 5) argues that:

Difficulties include the observability of results over time, a lack of bodies to measure grand-scale worldwide projects as well as the lack of systemic and objective examination criteria for not occurred risks as well as multiple stakeholder channels to discuss.

For example, Laurent (2020) explains how a focus on territorial emissions (i.e., the approach of the Monitoring Mechanism) ignores imported consumption-based emissions, for which the existing monitoring regimes and the EGD do not account, and whose omission paints a skewed picture of the EU's emissions reductions and the impact of its climate policies. Governing with turbulence, in particular, requires a broad knowledge of the impacts of the EGD, given the potential for the emergence of unexpected outcomes. Crucially, the efficacy of these monitoring schemes is yet to be assessed, a key gap that the proposed framework has highlighted. There appears to be a tendency to integrate different monitoring streams to generate overall assessment, as is the case in the Energy Union reporting. The new Governance Regulation has also placed a stronger emphasis on ex-ante reporting, whose effect on "policy shaping," especially by the European Commission, remains a key subject for future research (see Knodt \& Ringel, 2018). The new EGD monitoring efforts and the dashboard could potentially generate new effects, especially when monitoring happens across policy sectors rather than on a sectoral basis, but it is too soon to tell while the exact institutional design and monitoring provisions remain unknown.

An additional effect of policy monitoring may be its use in other policy evaluation exercises, that is, "careful retrospective assessment of the merit, worth and value of administration, output and outcome of government interventions, which is intended to play a role in future, practical action situations" (Vedung, 1997, p. 3). In contrast to policy monitoring, policy evaluation is a broader exercise, which often aims to assess the causal effect of a policy, frequently drawing on programme theory. In doing so, monitoring data may be a helpful ingredient, but only to the extent that it is relevant to and usable in policy evaluation. In the implementation of the EGD, the question will ultimately be whether policy monitoring ends up as a "paper tiger" (Niederberger \& Kimble, 2011) or whether it becomes one of the crucial institutional conditions that help accelerate and steer the much-needed low-carbon transition (Roberts et al., 2018). As Patton (2021) argues, "the greatest danger for 
evaluators in times of turbulence is not the turbulenceit is to act with yesterday's criteria." Without a better understanding of policy monitoring practices and their effects, scholars and practitioners may well discover that the devil of governing in turbulent governance environments emerges through the details of monitoring.

\section{Acknowledgments}

The author thanks the thematic issue and journal editors, as well as anonymous peer reviewers for their constructive comments and suggestions, which strengthened the article. The author presented an earlier version of this article at the 2018 ECPR General Conference in Hamburg, Germany, as well as at a 2020 ECPR Joint Sessions Workshop (online). The conference participants, Andrew Jordan and especially Michèle Knodt deserve credit for their feedback and support. The early writing stages were supported by the German Federal Ministry of Education and Research (Reference: 03SFK4PO, Consortium ENavi, Kopernikus). Björn Schulz provided research assistance.

\section{Conflict of Interests}

The author declares no conflict of interest.

\section{References}

Aldy, J. E. (2014). The crucial role of policy surveillance in international climate policy. Climatic Change, 126(3/4), 279-292.

Aldy, J. E. (2018). Policy surveillance: Its role in monitoring, reporting, evaluating and learning. In A. Jordan, D. Huitema, H. van Asselt, \& J. Forster (Eds.), Governing climate change: Polycentricity in action? (pp. 210-227). Cambridge University Press.

Ansell, C. K., Trondal, J., \& Øgård, M. (2017). Turbulent governance. In C. K. Ansell, J. Trondal, \& M. Øgård (Eds.), Governance in turbulent times (pp. 1-23). Oxford University Press.

Averchenkova, A., Fankhauser, S., \& Nachmany, M. (2017). Trends in climate change legislation. Edward Elgar.

Batterbury, S. C. (2006). Principles and purposes of European Union cohesion policy evaluation. Regional Studies, 40(02), 179-188.

Bocquillon, P., Brooks, E., \& Maltby, T. (2020). Speak softly and carry a big stick: Hardening soft governance in EU energy and health policies. Journal of Environmental Policy and Planning, 22(6), 843-856.

Bovens, M., Hart, P., \& Kuipers, S. (2006). The politics of policy evaluation. In M. Moran, M. Rein, \& R. E. Goodin (Eds.), The Oxford handbook of public policy (pp. 319-335). Oxford University Press.

Bürgin, A. (2021). Modernisation of environmental reporting as a tool to improve the European Commission's regulatory monitoring capacity. Journal of
Common Market Studies, 59(2), 354-370. https://doi. org/10.1111/jcms.13093

Calvo Buendia, E., Tanabe, K., Kranjc, A., Baasansuren, J., Fukuda, M., Ngarize, S., Osako, A., Pyrozhenko, Y., Shermanau, P., \& Federici, S. (2019). 2019 refinement to the 2006 IPCC guidelines for national greenhouse gas inventories. Intergovernmental Panel on Climate Change. https://www.ipcc.ch/report/ 2019-refinement-to-the-2006-ipcc-guidelines-fornational-greenhouse-gas-inventories

Cumming, J., \& Forbes, S. (2012). Better public services: The case for monitoring and evaluation. Policy Quarterly, 8(3), 49-55.

De Francesco, F., Leopold, L., \& Tosun, J. (2020). Distinguishing policy surveillance from policy tracking: Transnational municipal networks in climate and energy governance. Journal of Environmental Policy and Planning, 22(6), 857-869.

Dobbs, M., Gravey, V., \& Petetin, L. (2021). Driving the European Green Deal in turbulent times. Politics and Governance, 9(3), 316-326.

Dunn, W. N. (2018). Monitoring observed policy outcomes. In W. N. Dunn (Ed.), Public policy analysis (6th ed., pp. 250-319). Routledge.

Eggleston, H. S., Buendia, L., Miwa, K., Ngara, T., \& Tanabe, K. (2006). 2006 IPCC guidelines for national greenhouse gas inventories. Intergovernmental Panel on Climate Change.

European Commission. (2019). The European Green Deal. https://eur-lex.europa.eu/resource.html?uri=cellar: b828d165-1c22-11ea-8c1f-01aa75ed71a1.0002.02/ DOC $1 \&$ format=PDF

Eurostat. (2016). Energy balance for EU28. http://ec. europa.eu/eurostat/cache/sankey/sankey.html

Gerlak, A. K., Heikkila, T., Smolinski, S. L., Huitema, D., \& Armitage, D. (2017). Learning our way out of environmental policy problems: A review of the scholarship. Policy Sciences, 51, 335-371.

Gupta, A., \& Mason, M. (2016). Disclosing or obscuring? The politics of transparency in global climate governance. Current Opinion in Environmental Sustainability, 18, 82-90.

Haigh, N. (1996). Climate change policies and politics in the European Community. In T. O'Riordan \& J. Jäger (Eds.), Politics of climate change: A European perspective (pp. 155-185). Routledge.

Held, D., \& Roger, C. (2018). Three models of global climate governance: From Kyoto to Paris and beyond. Global Policy, 9(4), 527-537.

Hildén, M., Jordan, A. J., \& Rayner, T. (2014). Climate policy innovation: Developing an evaluation perspective. Environmental Politics, 23(5), 884-905.

Hillebrandt, M. (2020). Access to environmental information in the EU: A great policy no-one needs? JCMS: Journal of Common Market Studies. Advance online publication. https://doi.org/10.1111/jcms.13164

Howes, T. (2010). The EU's new renewable energy directive $(2009 / 28 / E C)$. In S. Oberthür \& M. Pallemaerts 
(Eds.), The new climate policies of the European Union: Internal legislation and climate diplomacy (pp. 117-150). Brussels University Press.

Hsu, A., Höhne, N., Kuramochi, T., Roelfsema, M., Weinfurter, A., Xie, Y., Lütkehermöller, K., Chan, S., CorfeeMorlot, J., \& Drost, P. (2019). A research roadmap for quantifying non-state and subnational climate mitigation action. Nature Climate Change, 9(1), 11-17.

Hughes, S., Tozer, L., \& Giest, S. (2019). The politics of data-driven urban climate change mitigation. In J. Van Der Heijden, H. Bulkeley, \& C. Certomà (Eds.), Urban climate politics: Agency and empowerment (pp. 116-134). Cambridge University Press.

latridis, M., Tourkolias, C., Jamek, A., Pickl, N., Andersen, J., Kjaer, T., Kudrenickis, I., Klavs, G., Rekis, J., Maric, L., Matosovic, M., Dragovic, M., Ringel, M., Skema, R., Masaitis, S., Dimitrov, K., Panevski, S., Jambor, E., Nemeth, M., \& Struss, B. (2015). Synthesis report on M\&V schemes and coordination mechanisms in EU countries. MultEE Project.

latridis, M., Tourkolias, C., Jamek, A., Pickl, N., Andersen, J., Kjaer, T., Kudrenickis, I., Klavs, G., Rekis, J., Maric, L., Matosovic, M., Dragovic, M., Ringel, M., Skema, R., Masaitis, S., Dimitrov, K., Panevski, S., Jambor, E., Nemeth, M., \& Struss, B. (2016). Synthesis report on European best practices for M\&V schemes and coordination mechanisms. MultEE Project.

Jevnaker, T., \& Saerbeck, B. (2019). EU agencies and the Energy Union: Providing useful information to the Commission? Politics and Governance, 7(1), 60-69.

Jones, S. (2010). The social impact of the crisis: Is European Union monitoring working? Journal of Poverty and Social Justice, 18(3), 295-303.

Kanellakis, M., Martinopoulos, G., \& Zachariadis, T. (2013). European energy policy-A review. Energy Policy, 62, 1020-1030.

Kenney, M. A., \& Gerst, M. D. (2021). Synthesis of indicators, datasets, and frameworks available to establish resilience and adaptation indicators: Case study of Chesapeake Bay region, USA. Current Climate Change Reports, 7, 35-44.

Knodt, M., \& Ringel, M. (2018). The European Commission as a policy shaper-Harder soft governance in the Energy Union. In J. Ege, M. W. Bauer, \& S. Becker (Eds.), The European Commission in turbulent times (pp. 181-206). Nomos.

Knodt, M., Ringel, M., \& Müller, R. (2020). 'Harder' soft governance in the European Energy Union. Journal of Environmental Policy and Planning, 22(6), 787-800.

Küchler, S., \& Meyer, B. (2012). Was Strom wirklich kostet [The real cost of electricity]. Greenpeace Energy. http://www.foes.de/pdf/2012-08-Was_Strom_ wirklich_kostet_kurz.pdf

Lasswell, H. D. (1965). World politics and personal insecurity. The Free Press.

Laurent, É. (2020). The European Green Deal: Bring back the new (OFCE policy brief 63). Observatoire français des conjonctures économiques.
Leeuw, F. L. (2010). Benefits and costs of evaluation: An essay. Zeitschrift für Evaluation, 9(2), 211-227.

Lehtonen, M. (2015). Indicators: Tools for informing, monitoring or controlling? In A. Jordan \& J. Turnpenny (Eds.), The tools of policy formulation: Actors, capacities, venues and effects (pp. 76-99). Edward Elgar.

Mastenbroek, E., van Voorst, S., \& Meuwese, A. (2016). Closing the regulatory cycle? A meta evaluation of ex-post legislative evaluations by the European Commission. Journal of European Public Policy, 23(9), 1329-1348.

Mayne, J., \& Zapico-Goñi, E. (1997). Effective performance monitoring: A necessary condition for public sector reform. In J. Mayne \& E. Zapico-Goñi (Eds.), Monitoring performance in the public sector: Future directions from international experience (pp. 3-29). Transaction Publishers.

Niederberger, A. A., \& Kimble, M. (2011). MRV under the UN climate regime: Paper tiger or catalyst for continual improvement? Greenhouse Gas Measurement and Management, 1(1), 47-54.

OECD-DAC. (2002). Glossary of key terms in evaluation and results based management.

Ostrom, E. (1990). Governing the commons: The evolution of institutions for collective action. Cambridge University Press.

Patton, M. Q. (2021). Evaluation criteria for evaluating transformation: Implications for the coronavirus pandemic and the global climate emergency. American Journal of Evaluation, 2(1), 53-89.

Peeters, M., \& Athanasiadou, N. (2020). The continued effort sharing approach in EU climate law: Binding targets, challenging enforcement? Review of European, Comparative \& International Environmental Law, 29(2), 201-211.

Pereira, G. I., \& da Silva, P. P. (2017). Energy efficiency governance in the EU-28: Analysis of institutional, human, financial, and political dimensions. Energy Efficiency, 10(5), 1279-1297.

Puaschunder, J. M. (2021, March 1). Monitoring and evaluation (M\&E) of the green new deal (GND) and European Green Deal (EGD) [Paper presentation]. 21st Research Association for Interdisciplinary Studies (RAIS) Conference.

Radaelli, C. M. (2018). Halfway through the better regulation strategy of the Juncker Commission: What does the evidence say? JCMS: Journal of Common Market Studies, 56(S1), 85-95.

Ringel, M. (2017). Energy efficiency policy governance in a multi-level administration structure-Evidence from Germany. Energy Efficiency, 10(3), 753-776.

Rist, R. C., \& Stame, N. (2011). From studies to streams: Managing evaluative systems. Transaction Publishers.

Roberts, C., Geels, F. W., Lockwood, M., Newell, P., Schmitz, H., Turnheim, B., \& Jordan, A. (2018). The politics of accelerating low-carbon transitions: Towards a new research agenda. Energy Research \& 
Social Science, 44, 304-311.

Rosenow, J., Forster, D., Kampman, B., Leguijt, C., Pato, Z., Kaar, A., \& Eyre, N. (2015). Study evaluating the national policy measures and methodologies to implement Article 7 of the energy efficiency directive. CE Delft.

Sabel, C. F. (1993). Learning by monitoring: The institutions of economic development. In N. J. Smelser \& R. Swedberg (Eds.), The handbook of economic sociology (pp. 137-165). Princeton University Press.

Schoenefeld, J. J., Hildén, M., \& Jordan, A. J. (2018). The challenges of monitoring national climate policy: Learning lessons from the EU. Climate Policy, 18(1), 118-128.

Schoenefeld, J. J., Hildén, M., \& Schulze, K. (in press). Policy innovation. In D. Russel \& N. Kirsop-Taylor (Eds.), Handbook on the governance of sustainable development. Edward Elgar.

Schoenefeld, J. J., \& Jordan, A. J. (2017). Governing policy evaluation? Towards a new typology. Evaluation, 23(3), 274-293.

Schoenefeld, J. J., \& Jordan, A. J. (2019). Environmental policy evaluation in the EU: Between learning, accountability, and political opportunities? Environmental Politics, 28(2), 365-384.

Schoenefeld, J. J., \& Jordan, A. J. (2020). Towards harder soft governance? Monitoring climate policy in the EU. Journal of Environmental Policy and Planning, 22(6), 774-786.

Schoenefeld, J. J., \& Knodt, M. (2021). Softening the surface but hardening the core? Governing renewable energy in the EU. West European Politics, 44(1), 49-71.

Schoenefeld, J. J., \& Rayner, T. (2019). Monitoring energy policy. In M. Knodt \& J. Kemmerzell (Eds.), Handbook of energy governance in Europe. Springer. https:// doi.org/10.1007/978-3-319-73526-9_43-1

Schoenefeld, J. J., Schulze, K., Hildén, M., \& Jordan, A. (2019). Policy monitoring in the EU: The impact of institutions, implementation and quality. Politische Vierteljahresschrift, 60(4), 719-741.

Schoenefeld, J. J., Schulze, K., Hildén, M., \& Jordan, A. J. (2021). The challenging paths to net-zero emissions: Insights from the monitoring of national policy mixes. The International Spectator, 56(3), 24-40.

Tosun, J. (2012). Environmental monitoring and enforcement in Europe: A review of empirical research. Environmental Policy and Governance, 22(6), 437-448.

Trondal, J. (2016). Governance in turbulent administrative systems. In C. K. Ansell, J. Trondal, \& M. Øgård (Eds.), Governance in turbulent times (pp. 159-179). Oxford University Press.

Vedung, E. (1997). Public policy and program evaluation. Transaction Publishers.

Waterman, R. W., \& Wood, B. D. (1993). Policy monitoring and policy analysis. Journal of Policy Analysis and Management, 12(4), 685-699.

Weikmans, R., Asselt, H. v., \& Roberts, J. T. (2020). Transparency requirements under the Paris Agreement and their (un)likely impact on strengthening the ambition of nationally determined contributions (NDCs). Climate Policy, 20(4), 511-526.

Weiss, C. H. (1993). Where politics and evaluation research meet. Evaluation Practice, 14(1), 93-106.

Yamin, F., \& Depledge, J. (2004). The international climate change regime: $A$ guide to rules, institutions and procedures. Cambridge University Press.

\section{About the Author}

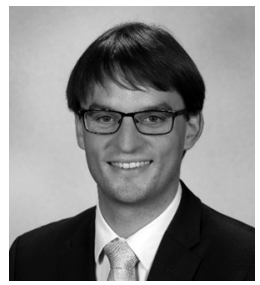

Jonas J. Schoenefeld (PhD) is a scientist at the Institute for Housing and Environment (IWU) in Darmstadt, Germany, and a visiting researcher at the Tyndall Centre for Climate Change Research, School of Environmental Sciences, University of East Anglia in Norwich, UK. His research focuses on governance and public policy, and he has particularly explored climate, environmental, and energy policy monitoring and evaluation in recent years (Photo by Foto Stommel). 